\title{
FENOMENA DZIKIR BERJAMAAH SEBAGAI SARANA PEREKAT SOSIAL
}

\author{
Alamul Huda \\ Fakultas Syariah UIN Maulana Malik Ibrahim Malang \\ Email : alamulhuda09@gmail.com
}

\begin{abstract}
Abstrak
The existence of Islam as a religion of da'wah dan humanity, which means, that the basic concept of Islamic theories are covers about all the conditions of human life, which in a sense-not only discuss the purely worship (ibadah mahdloh), but also talk about aspects of improvements in social community and society. In the present context, Manaqib Sheikh Abdul Qadir al-Jilani has been designed to be a remembrance and famous and known as a unique religious movement and became a "breath and reason" the spirituality of marginalized communities (edges), according to the facts and truth, the reality of religious movements can affect, keep and maintain the norms and morality (moral) social. Where there, in the presence of this movement and behavior concepts silaturrahim (among jama'a manaqiban), awakening the main attitude in life, personality, nice and good character. And also in fact, the relationship of reason and the reconstruction of the socio-spirituality of the theological community has a strong relationship from the perspective and view point of "riayatul maslahat".

Keberadaan Islam sebagai agama dakwah dan kemanusiaan, yang berarti, bahwa konsep dalam teoriteori keislaman bahasannya mencakup tentang seluruh kondisi kehidupan manusia, yang dalam artianbukan hanya membahas ibadah mahdloh (murni bersifat ilahiah) saja tetapi juga berbicara tentang aspek-aspek perbaikan (moral dan sosial) di dalam masyarakat. Dalam konteks kekinian, Manaqib Syaikh Abd al-Qadir al-Jailani yang telah di desain menjadi sebuah dzikir dan kemudian masyhur dan di kenal sebagai sebuah gerakan keagamaan yang unik dan menjadi sebuah "nalar dan nafas" spiritualitas masyarakat marjinal (pinggiran); menurut fakta, pada kenyataannya-gerakan keagamaan tersebut- dapat mempengaruhi dan menjaga norma dan moralitas (akhlak) sosial. Dimana, dalam gerakan ini terdapatnya konsep dan perilaku silaturrahim (diantara jama'ah manaqiban), terbangunnya sikap utama dalam menjalani hidup, kepribadian dan karakter yang baik. Dan pada kenyataannya, hubungan nalar spiritualitas dan rekonstruksi sosio-teologis masyarakat memiliki hubungan yang kuat dari sisi titik pandang dan perspektif ri'ayatul maslahat( public interest)
\end{abstract}

Kata Kunci: Islamic religious movement, social morality, public interest

Islam sebagai agama dakwah dan kemanusiaan, yang memiliki kekuatan sinergis antara dualitas ganda penghambaan seorang mukallaf pada Allah SWT dan pengabdian tulus pada alam dan manusia serta kemanusiaan. berangkat dari spektrum pertama -yang- erat berkaitan dengan realitas teologis Ilahiyah, yang dikenal dengan sebutan Hablumminallah dan yang kedua erat dengan hakekat sosiologis Insaniyyah yang lazim di sebut Hablumminannas. Dari dualitas sikap yang dihadirkan dalam setiap diri (baca: pribadi) seseorang ini, pada akhirnya membuahkan hasil dan berimbas pada setiap perilaku keseharian seorang muslim adalah bernilai ibadah, yang meniscayakan cakupannya dalam dua prinsip utama yaitu agar menjadi seorang muslim yang bertauhid dengan ultimate spirit
"Laa Ilaa ha Illallah" dan hidup bermasyarakat, agar selalu memelihara hubungan baik dengan Allah Swt dan juga mencipta keharmonisan pergaulan dan hubungan dengan sesama manusia; yang keduanya dilakukan dalam rangka meraih ridha dan beribadah kepada Allah SWT. ${ }^{1}$ Bisa di pahami disini, bahwa entitas kebutuhan jasmaniah dan ruhaniah yang terserap alamiah dalam diri manusia menjadi akar utama dalam peran sertanya sebagai makhluk pribadi dan makhluk sosial, khususnya dalam pergulatan hidup keseharian yang dijalani, -dimana seringkalimanusia yang berkelindan dan bertungkus lumus dengan tujuan memenuhi tuntutan kehidupan, baik

Syarifudin, Amir, Garis-Garis Besar Fiqh, (Bogor, Prenada Media, 2003). Hal. 12. 
yang berkaitan dengan mengais nafkah keluarga sebagai suatu kewajiban yang tak terelakkan atau menjelajah alam semesta dalam upaya menggali ayat-ayat kauniyah, dan memecah misteri segala ciptaanNya. Lambat laun -dalam mencapai tujuan itu-, secara alamiah, lalu mereka membentuk komunitas masyarakat yang menghasilkan kebutuhannya secara mandiri bahkan dapat memproduksi (menghasilkan) kebudayaannya sendiri. Apabila dilacak secara alamiah di sini, secara psikologis akan mengarah pada naluri manusia, dimana secara garis besar, memiliki kecenderungan untuk hidup bersama dan berkumpul mewujudkan keinginan yang sama, dan hal ini seringkali dipandang sebagai kebiasaan.

\section{Teori Tentang Perilaku Manusia, Sosial dan Masyarakat}

Bila mengulas kebiasaan (habitual) manusia, adalahmerupakan pola perilakuyang tidak di wariskan, namun dibangun dari hasil runtutan pengalaman, terbangun dari naluri atau nalar bagi manusia, sebagaimana John Dewey (1859-1952) melihat bahwa naluri tidak membentuk lembaga, namun lembagalah yang membentuk naluri, hal tersebut menurutnya merupakan elemen bawah sadar yang terjadi begitu saja adanya. Melihat adanya kelebihan pada naluri manusia, adalah Ibnu Maskawaih (932-1030) seorang filosof etika Muslim, menonjolkan kelebihan jiwa manusia atas jiwa binatang, dengan adanya kekuatan berfikir yang menjadi sumber pertimbangan dalam tingkah laku dan melakukan sesuatu yang selalu mengarah kepada kebaikan. ${ }^{2}$ Dari pandangan ini, aspek pikiran (mind) pada manusia, menjadi sentral dan penopang keunggulan manusia dibanding makhluk lain yang diciptakan Allah SWT. Bahkan kekuatan rasionalitas manusia merupakan kunci dalam membangun peradaban sosial dan masyarakatnya. Selanjutnya ketika membahas tentang hubungan manusia dengan hal sosial di sekelilingnya, John Dewey menyatakan, bahwa manusia adalah makhluk sosial yang berarti semua tindakannya diberi cap oleh masyarakatnya. Sumbangan John Dewey terletak pada pandangannya bahwa pikiran (mind) seseorang berkembang dalam rangka untuk menyesuaikan dan dengan lingkungan. ${ }^{3}$ Pandangan bahwa manu-

\footnotetext{
2 Ibnu Maskawaih membagi kekuatan jiwa (kebaikan) pada manusia menjadi tiga tingkatan, antara lain:

Dari tingkat yang paling rendah disebutkan urutannya sebagai berikut:

1) Al nafs al bahimiyah (nafsu kebinatangan) yang buruk.

2) Al nafs al sabu'iah (nafsu binatang buas) yang sedang

3) Al nafs al nathiqah (jiwa yang cerdas) yang baik

Lihat: http://abulraihan.wordpress.com/pemikiran-ibnu-maskawaih-dan-ibnuthufail/

3 http://pustaka.ut.ac.id/-teori-sosiologi-modern
}

sia berkecenderungan adaptif dengan lingkungan yang dihadapi. Sedang pada tahun 1890, Wiliam James (1842-1910) dengan lugas menyatakan bahwa: "yang dianut psikolog dewasa ini, adalah pernyataan bahwa kehidupan manusia dikuasai nalar, sedangkan hewan dikendalikan naluri". ${ }^{4}$ Selanjutnya, adalah George Herbert Mead (1863-1931) seorang filosof dan psikolog modern, yang berpendapat bahwa manusia merupakan makhluk yang paling rasional dan memiliki kesadaran akan dirinya. Di samping itu, sebagaimana pendapat Darwin, di sini Mead juga menyatakan bahwa dorongan biologis memberikan motivasi bagi perilaku atau tindakan manusia, dan dorongan-dorongan tersebut mempunyai sifat sosial, serta komunikasi adalah ekspresi dari perasaan. ${ }^{5}$ Berkaitan dengan bahasan relasi manusia dengan sosial dan lingkungannya tersebut, terbentuklah satu susunan masyarakat sebagai bentuk dari kerjasama fungsional dengan nilai yang saling menguntungkan, dimana di dalamnya terdapat kestabilan sosial yang disanggah oleh kesepakatan dasar atas nilai-nilai. Dalam pandangan ini ditekankan, bahwa secara kentara terdapatnya tarik-menarik antar kepentingan masing-masing individu, solidaritas, integrasi, kerjasama, dan stabilitas komunal dipersatukan karena adanya kesamaan budaya, cara pandang, prilaku dan kesepakatan atas norma serta nilai-nilai dasar yang sama.

Adapun secara terminologi geografis dan sistem sosial, masyarakat yaitu: adanya kesatuan yang tetap dari orang-orang yang hidup di daerah tertentu dan bekerjasama dalam kelompok-kelompok, berdasarkan kebudayaan yang sama untuk mencapai kepentingan yang sama. Sementara sejurus dengan hal itu, di sebutkan secara sistem sosial, masyarakat merupakan sekolompok orang yang tinggal bersama dalam suatu waktu yang cukup lama, sehingga terdapat susunansusunan diantara mereka ${ }^{6}$

Dari sisi Perkembangan masyarakat, dalam struktur masyarakat lalu timbul berbagai persoalan yang berasal dari proses interaksi masyarakat dengan dunia luar (eksternal), dan bisa jadi merupakan pergumulan antara standar moral yang dipahami serta dijalani secara turun-temurun dengan konteks keterbukaan informasi di tengah masyarakat sehingga me-

\footnotetext{
4 Soeryono soekanto. Mengenal Tujuh Tokoh Sosiologi"(Jakarta, Raja Grafindo Persada, 2002). Hal . 221

http://pustaka.ut.ac.id /-teori-sosiologi-modern

6 A society or a human society is: (1) a group of people related to each other through persistent relations; (2) a large social grouping that shares the same geographical or virtual territory, subject to the same political authority and dominant cultural expectations. lihat:http://en.wikipedia.org/wiki/Society, http://id.shvoong.com/society-and-news/culture/definisimasyarakat-darisudut-pandang/
} 
munculkan (baca; menimbulkan) perubahan perilaku negatif seperti sikap apatis terhadap keadaan, a moral dan perilaku yang jauh dari tuntunan moral sosial dan norma-norma kolektif, yang dalam bahasa Emile Durkheim (1858-1917), munculnya gejala yang menjadi penyimpangan perilaku sosial yang disebut anomie yakni: satu keadaan dimana perubahan dalam masyarakat yang cepat karena semakin meningkatnya pembagian kerja menghasilkan suatu "kebingungan" tentang norma dan semakin meningkatnya sifat yang tidak pribadi dalam kehidupan sosial, yang akhirnya mengakibatkan runtuhnya norma-norma sosial yang mengatur perilaku. ${ }^{7}$ Sedang konsep masyarakat tradisional dalam perspektif Durkheim sendiri, merupakan masyarakat-masyarakat yang bersifat 'mekanis' dan dipersatukan oleh kenyataan bahwa setiap orang lebih kurang sama, dan karenanya mempunyai banyak kesamaan di antara sesamanya. Masyarakat tradisional, kata Durkheim, adanya kesadaran kolektif sepenuhnya mencakup kesadaran individual, normanorma sosial kuat dan perilaku sosial diatur dengan rapi. ${ }^{8}$ tentunya ketika standarisasi norma yang di topang oleh kesadaran kolektif dalam masyarakat tradisional mulai "runtuh dan goyah" akhirnya menyebabkan goyahnya kemapanan "moral" yang dirasakan masyarakat. Dan "kesadaran kolektif" masyarakat, dimana adanya kesepakatan bersama atas tindakan, sikap dan perilaku yang menunjukkkan adanya sebuah kecenderungan -dalam artian- adanya kesamaan antar individu dan kelompok (konsesus) dalam sebuah masyarakat. Selanjutnya mengaca pada analisis Herbert spencer (1820-1903), yang berpandangan bahwa secara alamiah manusia pada konsep dasarnya memiliki sifat condong pada kehidupan politik, agama dan lain sebagainya; dan dari dorongan alamiah inilah muncul organisasi sosial, ${ }^{9}$ yang menjalar pada satu sikap dan perilaku keberagamaan yang selanjutnya mengkristal lalu membentuk satu organisasi atau gerakan sosial-keagamaan di dalam masyarakat.

Beranagkat dari sini, terjadilah dialog konstruktif simbiosis mutualistik yang bersifat sosio-teologis (masyarakat dan agama) dalam satu nampan kolektivitas masyarakat marjinal. Peletakan simbol "marjinal" hingga disematkan di sini, karena -pada posisi ini- masyarakat yang nota bene sebagai subyek pelaku gerakan keberagamaan ini adalah masyarakat baik yang terpinggirkan secara komunikasi politik dan sosial, pemahaman keagamaan dan sistem pemi-

\footnotetext{
http://id.wikipedia.org/wiki/Emile Durkheim http://id.wikipedia.org/wiki/Emile Durkheim Soeryono, Mengenal... Hal. 179.
}

kiran maupun masyarakat yang dipotret secara lokasi geografis; yang daerahnya berada di wilayah minus baik tepian pantai ataupun lereng perbukitan dan pegunungan. Unsur marjinal merupakan bahasa lain dari satu komunitas yang di sana melambangkan sifat keluguan dalam sikap dan cara berpikir, yang muaranya akan melahirkan perilaku beragama dengan "pasrah, mengikut dan manut (bhs. jawa)" istilahnya taqlid pada ucapan, tindak dan perilaku keberagamaan tokoh agama, ulama' yang mejadi panutan masyarakat di wilayah tersebut. potret ini termasuk dalam masalah moral dan akhlak, biasanya masyarakat awam dengan seksama akan serta merta menduplikasi akhlak tokoh agama yang dianggap sebagai panutan, di samping norma - norma yang (telah) disepakati.

\section{Islam dan Nilai-Nilai Sosial Masyarakat}

SejurusdengannilaiyangterkandungdalamIslam tentang manusia, alam dan sosial, secara sederhana dapat dilihat bahwa Islam yang dikenal sebagai agama yang mengusung prinsip rahmatan lil alamin, diutus Rasulullah SAW juga dengan menyandang prinsip ini. Keniscayaan Islam sebagai rahmat, di harapkan menjadi penggerak utama atau bahkan "nyawa" bagi tercapainya cita-cita kesejahteraan sosial yang berkeadilan di dalam masyarakat. Dalam satu artian, bahwa nilai yang diusung sejak Islam hadir ke dunia dengan Rasulullah SAW sebagai pembawa risalah utama, sudah memproklamasikan adagium bahwa Islam adalah "rahmat" dan juga "hidayat" bagi segenap manusia dan makhluk lain yang "mendampingi" keberadaan manusia di dunia yang disebut alam semesta ini. Dalam al-Qur'an di sebutkan, sifat dan bersikap kasih sayang serta lemah lembut merupakan open road (pembuka jalan) atau sebagai washilah bagi kesuksesan dalam pergaulan dan segalanya, disebutkan dalam surat Ali Imran: "Maka disebabkan rahmat dari Allahlah kamu berlaku lemah lembut terhadap mereka. Sekiranya kamu bersikap keras lagi berhati kasar, tentulah mereka menjauhkan diri dari sekelilingmu, karena itu ma'afkanlah mereka, mohonkanlah ampun bagi mereka, dan bermusyawaratlah dengan mereka dalam urusan itu "(QS. Ali Imran : 159). Pesan dari ayat ini menyatakan bahwa sifat lemah lembut (pada sesama) merupakan jiwa dari agama Islam.

Diantara tujuan Islam dalam membangun "akhlak sosial" dan pranata sosial, termaktub dalam firman Allah SWT, yang menandaskan hakekat "taaruf" atau sikap saling mengenal antara laki-laki dan perempuan dalam upaya membangun satu tata- 
nan masyarakat ideal, sebagaimana ayat yang artinya: "Wahai Manusia, Kami ciptakan kamu dari laki-laki dan perempuan dan kami jadikan kamu berbangsabangsa dan bersuku-suku agar kamu saling mengenal. Sesungguhnya yang paling mulia diantaramu di sisi Allah adalah yang paling takwa. Sesungguhnya Allah Maha Mengetahui dan Maha Mengenal" (QS. AlHujarat: 13), dan secara naluriah, dalam memperkuat konsep saling mengenal atau taaruf di atas diperlukan kekuatan akhlak dan moral (power of ethics and morality) sehingga hubungan antar ke-saling mengenal-an ini menjadi langgeng dan berketerusan dan berlandaskan nilai dan tuntunan agama.

Tesis ini tumbuh dan ternyatakan dengan clear bahwa dalam hubungan sosial bermasyarakat, Islam adalah agama yang mengedepankan dan berpijak pada konsep fleksibilitas, toleransi yang tegas, sifat keadilan yang dinamis sehingga sesuai serta dapat di jalankan di segala zaman. Kekuatan akhlak Rasulullah SAW, serta keteguhan perjuangan beliau dalam mensukseskan dan membentuk satu bangunan sistem pranata sosial masyarakat baru yang Islami, yang mana kedatangan Rasulullah SAW telah membawa perubahan yang besar dan memiliki imbas yang sangat luar biasa, yang mempengaruhi secara paten dalam melakukan reformasi establisitas struktur sukuisme arab yang feodalistik dan primordial serta hedonis.

Kekuatan akhlak menjadi dominan dalam pengembangan dan penyebarluasan agama Islam sejak awal kali diturunkan. Menilik definisi kata "akhlak" itu sendiri berasal dari bahasa Arab yaitu khalaqayahluqu, artinya menciptakan, (yang) dari akar kata ini pula, ada kata makhluk (yang diciptakan) dan kata khalik (pencipta), maka akhlak berarti segala sikap dan tingkah laku manusia yang datang dari pencipta (Allah SWT). Sedangkan moral berasal dari maros (bahasa latin) yang berarti adat kebiasaan, disinilah terlihat perbedaan antara moral dengan akhlak, dimana moral berbentuk adat kebiasaan ciptaan manusia, sedangkan akhlak berbentuk aturan-aturan yang mutlak kebenarannya yang pasti yang datang dari Allah SWT.

\section{Norma Agama dan Sosial; Tulang Punggung Akhlak Masyarakat}

Adanyanormayang telahmendarah daging dalam kehidupan sosial, yang nilai-nilai luhurnya menjadi penggerak utama moral masyarakat. Norma menjadi barometer utama masyarakat, yang digunakan dalam mengukur etika dan tata cara berprilaku (anggota masyarakat) didalamnya. Menurut beberapa pemikir ilmu sosial, secara eksplisit norma sendiri terbagi menjadi empat struktur tingkatan dan berdasarkan tingkatannya, norma di dalam masyarakat dibedakan menjadi empat, yaitu cara (usage), kebiasaan (Folkways), tata kelakuan (Mores) dan adat istiadat (Custom). Sedang apabila ditilik dari macam jenisnya, norma terbagi menjadi lima macam yaitu terdiri dari norma agama, norma kesusilaan, norma kesopanan, norma kebiasaan dan kode etik. Dari kelima norma ini, ada baiknya jika kita geledah pada norma agama. Dimana norma agama adalah segala sesuatu yang bersifat pemberian (given) dan wahyu (divine) dimana segala tata perilaku di sana bersandar penuh pada kode etik yang berasal dari Tuhan Yang Maha Esa, bersifat tetap dan konstan (qothiyatutssubut), memiliki sanksi dan aturan tegas, yaitu pahala bagi yang melaksanakan perintahNya dan dosa bagi yang meninggalkannya.

Sedang di beberapa daerah terdapat korelasi (ta'alluq) erat antara nilai pelaksanaan hukum agama, syariah terhadap para penduduk dengan kewibawaan kultural seseorang (baca: kiyai pen.). dimana perilaku keberagamaan mereka bergantung pada bagaimana kiyai tersebut mengamalkan agamanya. Sedang pada norma kesusilaan, adanya hukuman bagi pelaku yang melanggar kesusilaan atau moral di tengah masyarakat yang telah disepakati, dan umumnya tata norma yang berlaku itu tidak tertulis namun terasa kehadirannya. Sedang norma kesopanan dan norma kebiasaan adalah segala sesuatu yang dianggap sebagai bentuk kesopanan yang menyebabkan bagi individu yang mengikuti dan atau yang melakukannya mendapat penghargaan setimpal dan pengakuan yang bersifat disegani oleh komunitas masyarakat. Sedang pada norma kode etik dalam penerapannya adalah beberapa aturan yang tidak boleh dilanggar dan harus diikuti oleh individu dalam lingkungan masyarakat tertentu, dan biasanya, bagi pelanggar kode etik ini, akan mendapat sangsi pengucilan dari lingkungan pergaulan. ${ }^{10}$

\section{Islam dan Nilai-Nilai Sosial Masyarakat}

Secara sederhana, dalam pergaulan sosial Islam dikenal sebagai agama yang mengusung prinsip rahmat, dan diutusnya Rasulullah SAW sebagai rahmatan lil alamin (QS. Al-Anbiyaa:107), yang dipahami bahwa ajaran Islam itu mengandung makna bahwa kehadirannya memberikan rahmat kepada seluruh alam, termasuk di dalamnya lingkungan hidup, binatang, tumbuh-tumbuhan, dan seluruh umat

10 http://saiyanadia.wordpress.com/norma-dan-nilai-sosial/. 
manusia tanpa membedakan agama, golongan, etnis, dan peradaban. ${ }^{11}$ Adanya hal ini, Islam diharapkan dapat menjadi penggerak utama atau bahkan sebagai ruh bagi tercapainya cita-cita sosial di dalam masyarakat. Dalam artian, bahwa nilai yang diusung sejak Islam hadir ke dunia dengan Rasulullah SAW sebagai pembawa risalah utama, sudah memproklamasikan adagium bahwa Islam adalah "rahmat" dan "hidayat" bagi segenap manusia dan makhluk lain yang "mendampingi" keberadaan manusia di dunia yang disebut alam semesta.

Dalam al-Qur'an disebutkan, sifat dan bersikap kasih sayang serta lemah lembut merupakan open road (pembuka jalan) bagi kesuksesan dalam pergaulan dan segalanya, disebutkan dalam surat Ali Imran: "Maka disebabkan rahmat dari Allahlah kamu berlaku lemah lembut terhadap mereka. Sekiranya kamu bersikap keras lagi berhati kasar, tentulah mereka menjauhkan diri dari sekelilingmu, karena itu ma'afkanlah mereka, mohonkanlah ampun bagi mereka, dan bermusyawaratlah dengan mereka dalam urusan itu "(QS. Ali Imran : 159). Isyarat dari ayat ini menyatakan bahwa sifat lemah lembut merupakan jiwa dari agama Islam. Diantara tujuan Islam dalam membangun "akhlak sosial" dan pranata sosial, termaktub dalam firman Allah SWT, yang menandaskan hakekat "taaruf" atau sikap saling mengenal antara laki-laki dan perempuan dalam upaya membangun satu tatanan masyarakat ideal, sebagaimana ayat yang artinya: "Wahai Manusia, Kami ciptakan kamu dari laki-laki dan perempuan dan kami jadikan kamu berbangsa-bangsa dan bersukusuku agar kamu saling mengenal. Sesungguhnya yang paling mulia diantaramu disisi Allah adalah yang paling takwa. Sesungguhnya Allah Maha Mengetahui dan Maha Mengenal" (QS. Al-Hujarat: 13), dan secara naluriah, dalam memperkuat konsep saling mengenal atau taaruf di atas diperlukan kekuatan akhlak dan moral (power of ethics and morality) sehingga hubungan antar ke-saling mengenal-an ini menjadi langgeng dan berketerusan dan berlandaskan nilai dan tuntunan agama. Tesis ini tumbuh dan ternyatakan dengan performance bahwa dalam hubungan sosial bermasyarakat Islam adalah agama yang mengedepankan pada konsep fleksibilitas, toleransi, sifat keadilan yang dinamis sehingga sesuai serta dapat dijalankan di segala zaman. kekuatan akhlak Rasulullah SAW, serta keteguhan perjuangan beliau dalam mensukseskan, membentuk satu bangunan sistem pranata sosial masyarakat baru yang

11 http://www.republika.co.id/berita/ensiklopedia-islam/hikmah/-rahmatanlil-alamin
Islami. Kedatangan Rasulullah SAW telah membawa perubahan yang besar dan memiliki imbas yang sangat luar biasa, yang mempengaruhi kemapanan struktur sukuisme arab yang feodal dan primordial serta hedonis.

Dalam membangun moral dan karakter, salah satu yang sering kali menjadi pilihan utama adalah membenamkan nilai-nilai ajaran agama ke dalam pola pikir dan perilaku generasi sejak dini. Hal tersebut bisa berupa pelajaran tentang nilai religiusitas seperti mengaji al-Qur'an pada para ustadz-ustadzah dan guru-guru agama, mengikuti majlis-majlis dzikir dan majlis ta'lim yang ada di lingkungan sekitar, membuka program-program pengetahuan tentang alQur'an pada anak-anak di usia dini, sehingga setiap upaya yang bersifat dan bernilai spiritual keagamaan dapat membekas dalam memory seorang anak yang masih bersih. Di hati anak-anak yang masih putih ini kita tekankan akhlaq yang Islami, dan sesuai dengan tuntunan al-Qur'an seperti amar ma'ruf nahi mungkar, sifat jujur, amanah dan menghindari sifat khianat, ingkar janji, sifat iri, dengki dan dendam pada sesama, mengembangkan sifat toleran, tidak menang sendiri, demokratis, hormat pada perbedaan, mengajarkan sifat dermawan dan menghormati pada yang tua dan ta'dim pada guru serta menanamkan nilai-nilai kebaikan lainnya.

\section{Dzikir dalam Perspektif Eskatologis Sufisme dan Teologi Sosial}

Dalam kegemilangan sejarah perkembangan agama Islam, terdapat seorang sufi yang masyhur yaitu Abu al-Qasim Al-Qusyairy al-Naisabury, seorang ulama sufi yang hidup pada abad ke 4 hijriyah, pengarang (mualif) kitab al-Risalah al-Qusyairiyah mengemukakan pandangan dan pendapatnya yang fenomenal tentang tasawuf dan sufisme dalam Islam, beliau menyatakan bahwa tasawuf "merupakan bentuk amaliyah, ruh, rasa dan ajaran pekerti dalam Islam itu sendiri”. Beliau menyatakan, bahwa definisi di atas setelah membuktikan dari definisi-definisi yang ada tentang tasawuf dari para sufi besar sebelumnya. Dari seluruh pandangan para Sufi itulah akhirnya AlQusayri menyimpulkan bahwa Sufi dan Tasawuf memiliki terminologitersendiri, sama sekali tidak berawal dari etimologi, karena standar gramatika Arab untuk akar kata tersebut gagal membuktikannya. ${ }^{12}$ Dalam fenomena amal ubudiyah seorang yang dilakukan seorang hamba, dalam kacamata pandang seorang

\footnotetext{
12 Untuk berbagai definisi tasawuf, yang kurang lebih terdapat sekitar 27 definisi dari para sufi, dapat di lihat di http://akhfa.blogspot.com/2008/01/ definisi-tasawuf.html
} 
salikin sejati adalah beribadah kepada Allah SWT dibangun di atas dua pondasi yang besar yaitu: cinta yang sempurna kepada Allah SWT dan ketertundukan yang sempurna pada-Nya. Sifat "sempurna" dalam cinta dan ketertundukan inilah yang mendasari amal ibadah seorang hamba. Adalah sangatlah lumrah bila selalu ingat pada Allah SWT dengan berdzikir sebagai ungkapan rasa syukur dan tawakkal sebagai hamba yang merasa (perbuatannya) selalu diawasi oleh Allah SWT, dan juga sebagai rasa penuh dosa dan salah kepada Sang Maha Kuasa. Dengan kata lain, eksistensi (wujudiyah) tasawuf merupakan wujud cinta seorang hamba kepada Allah SWT dan RasulNya, pengakuan diri akan kewajibannya sebagai hamba pada Tuhannya dan terhadap sesama manusia di dalam amal kehidupan. ${ }^{13}$ Berangkat dari kesadaran terdalam akan kepasrahan pada ilahi, di sini relevansi dzikir menjadi bagian utama dalam pendekatan itu, juga merupakan bagian utama dari proses perjalanan seorang hamba menuju Tuhannya. Ritual manaqiban yang dilakukan oleh masyarakat pinggiran yang nota bene memiliki tradisi ahlussunnah wal jamaah, menganggap manaqiban adalah bagian dari upaya ngalap barokah dari sang waliyullah. Manaqiban sendiri di dalamnya terdapat rangkaian dzikir dan tahlil yang secara essensinya tidak lepas dari dimensi amal dan perilaku sufistik masyarakat awam.

\section{Dzikir Jama'i dan Manaqiban Cermin Nalar Spiritualitas Masyarakat Pinggiran}

Sebenarnya bila berbicara tentang nalar beragama masyarakat marjinal, tidak terlepas dari pola berpikir dan berprilaku masyarakat. Aktifitas religius yang bermuara dengan membentuk komunitas-komunitas yang berbentuk munculnya kelompok-kelompok minoritas keagamaan di tengah-tengah mereka seperti kelompok sholawatan, tahlilan, syarwaan (barzanji dan pembacaan dibaiyyah dalam bahasa madura), yasinan (membaca surat yasin), waqiahan (membaca surat al-Waqi'ah secara besama-sama) ${ }^{14}$, diba'an, yang asalnya ada secara sporadis namun lambat laun mengental menjadi sebuah tradisi gerakan keagamaan yang dilakukan mingguan. Sebagaimana hal tersebut, gerakan keagamaan manaqiban yaitu membaca manaqib Syaikh Abd al-Qadir al-Jailani yang masyhur dilaksanakan di sejumlah daerah di Indonesia. diantara menjamurnya manaqiban sebagai

\footnotetext{
13 http://irdy74.multiply.com/recipes/item/60.definisi tasawuf (penyejuk Jiwa).

14 Surat al-Waqiah di baca di tengah-tengah masyarakat karena di yakini sebagai surat pembuka rezki dan kekayaan
}

gerakan keagamaan, sebut saja di wilayah Kabupaten Probolinggo, Jawa Timur salah satu wilayah yang berada di pantai utara pulau jawa (Pantura), utamanya masyarakat yang berada di pinggiran pantai, pedesaan dan daerah pegunungan.

Menelisik lebih jauh, jika dipotret dari perspektif pembangunan nilai dan norma sosial melewati gerakan keagamaan, gerakan manaqiban bisa di anggap unik, karena fenomena mayoritas masyarakat yang mengikuti ritual manaqiban ini memiliki obsesi tersendiri yang bernuansa sosial, religius dan materi; yang minimal tercakup dalam tiga hal: mendapat (ketularan) karomah Syaikh Abd al-Qadir al-Jailani, memperkuatjalinan silaturahim dan kemudahan dalam mencari rezki (baca: mendapat rezki yang berlimpah). Oleh karena itu tidak jarang gerakan manaqib Syaikh Abd al-Qadir al-Jailani di ikuti mulai dari yang kecil dengan puluhan jamaah, atau dengan ratusan bahkan ribuan orang dengan waktu pelaksanaan yang variatif dari masing-masing jam'iyahnya seperti di laksananakan setiap malam sabtu(ritual manaqiban kubro malam sabtu wage), malam ahad (ritual manaqiban kubro malam ahad pon). Dalam ritual manaqiban, biasanya di baca runrutan perjuangan dan dakwah Syaikh Abd al-Qadir al-Jailani yang terangkum bersama ritual sufistik teologis-asketologis (bersifat keakheratan) serta majlis-majlis yang di adakan oleh beliau di "madrasah"nya. ${ }^{15}$ menjadi instrumen serta pengaruh tersendiri serta memiliki efek kuat terhadap “cara beragama para jama'ah manaqiban hingga kini. utamanya masyarakat pinggiran pantai, pedesaan dan daerah pegunungan di kabupaten probolinggo.

Sedikitnya bisa dimaklumi, secara sosial-religius, agaknya jamak diketahui, dalam rata-rata mentalitas masyarakat dengan kondisi geografis pinggiran dengan profesi sebagi petani, buruh tani, pedagang dan nelayan, yang nota bene memiliki pemahaman keagamaan mengikuti, patuh dan bertaklid pada tokoh yang agama/ kiyai /ustadz yang dapat dijadikan tempat bertanya serta tempat berkonsultasi tentang nilai-nilai agama dalam pelaksanaan ibadah bahkan secara kultural didaulat untuk memimpin hal-hal yang berkaitan dengan syariat, ambil contoh seperti pada prosesi aqad nikah, walimatul ursy, walimatul khitan, walimatul haj, acara dalam tahapan pasca

\footnotetext{
15 Istilah "madrasah" di pakai untuk memudahkan bagi umat islam saat itu untuk meminta wejangan keagamaan, fatwa, bimbingan dan menimba ilmu lewat majlis ta'lim yang di asuh langsung oleh syekh Abdul Qodir al-Jaelani di Baghdad, bahkan dalam satu nukilan kitab "Nurul Burhan di sebutkan: “...ma marroo muslimun 'alaa baabi madrosaty illaa khoffafalloohu 'an-hul 'adzaba yaumal qiyamati.." lihat: Syamsuri, Baidhowi,Penuntun Manaqib Syeikh Abdul Qadir al-Jailani dengan Terjemah", Surabaya, Apollo. Hal. 83-84.
} 
kematian jenazah mulai dari prosesi memandikan, mengkafani, memakamkan, talqin mayit, dan juga di lanjutkan ritual tahlil tepat pada 3 hari, 7 hari, 40 hari, dan 100 hari setelah kematian jenazah serta haul semua ini butuh tuntunan orang yang dianggap paham dibandingkan masyarakat awam, bisa di pahami bila mereka mengikuti- ritual lain yang di rintis oleh tokoh agama/kiyai/ustadz yang dianggap bila mengikutinya dapat menentramkan bathin mereka, hal ini sejalan dan sesuai dengan situasi umum masyarakat di daerah sekitarnya yang hampir dipastikan rata-rata melaksanakan hal tersebut. Menelisik lebih jauh, jika dipotret dari perspektif pembangunan nilai dan norma sosial melewati gerakan keagamaan, gerakan manaqiban bisa di anggap unik, karena fenomena mayoritas masyarakat yang mengikuti ritual manaqiban ini memiliki obsesi tersendiri yang bernuansa sosial, religius dan materi; yang minimal tercakup dalam tiga hal: mendapat (ketularan) karomah Syekh Abdul Qadir al-Jailani, memperkuat jalinan silaturahim dan kemudahan dalam mencari rezki (baca: mendapat rezki yang berlimpah). Oleh karena itu tidak jarang gerakan manaqib Syekh Abdul Qadir al-Jailani di ikuti mulai dari yang kecil puluhan, ratusan bahkan ribuan orang dengan waktu pelaksanaan yang variatif dari masing-masing jam'iyahnya seperti satu jam'iyyah manaqiban melaksanakan setiap malam sabtu (ritual manaqiban kubro malam sabtu wage), atau jam'iyyah yang lain setiap malam ahad (ritual manaqiban kubro malam ahad pon) dan tidak menutup kemungkinan bahwa anggota dari jama'ah jam'iyyah manaqib yang satu menjadi anggota jam'iyyah manaqib yang lain. Terlepas dari kebesaran nama beliau, pertanyaannya siapa sebenarnya Syaikh Abd al-Qodir al-Jailani yang begitu di kagumi dan nyaris di kultuskan ini?

Syaikh Abd al-Qodir al-Jailani, tak dapat di pungkiri, beliau adalah sosok ulama' dan seorang sufi agung yang pernah hadir dalam rentang panjang sejarah Islam. Beliau terlahir bernama lengkap Muhyi al Din Abu Muhammad Abdul Qadir ibn Abi Shalih Al-Jailani. Lahir di Jailan atau Kailan tahun 470H/1077 M kota Baghdad, sehingga di akhir nama beliau ditambahkan kata al-Jailani atau al-Kailani. Dalam tradisi rekam jejak sejarah (historical track record), beliau bergelar "Sulthan al-auliya wa al-arifin " (punggawa para waliyullah), imam al-ulama' al-Salikin, al-Sayyidi al-Syarif wa-al-sanadi al-'ithrif al-hasibi al-Nasib dzi al-Maqomul al- ' $a$ 'la atau gelar Qutb al-Rabbany (waliyullah yang utama), bahkan tidak jarang, juga mashur ditambahkan di depan nama beliau dengan tambahan sebutan "Ghauts al-a'dham" (sang penolong agung). ${ }^{16}$ Selanjutnya sebagai kasus menarik bagaimana peletakan ajaran dari Syaikh Abd al-Qodir al-Jailani yang kental bernuansa sufistik dengan format dzikir, ini secara massif di ikuti oleh sebagian besar masyarakat di pesisir pantai pulau jawa dengan bentuk dan sebutan yang berbeda tapi nyaris sama dalam prakteknya yaitu dengan membaca manakib (biografi) Syaikh Abd al-Qodir al-Jailani, dengan istilah teologiskultural seperti misalnya: manakiban, dzikir manakib, istighotsah-manaqib dan lain sebagainya. Sejatinya makna yang di tangkap dari manaqib adalah cerita atau kisah yang bagus atau baik ${ }^{17}$, jadi bila melihat dari sini, dapatlah dinilai bahwa kitab manaqib adalah kumpulan cerita atau kisah yang baik, akhlak mulia dan utama serta terpuji dari Syaikh Abd al-Qodir alJailani yang dapat di pakai sebagai pelajaran, renungan hikmah dalam, hidup, ibadah dan akhlak baik dalam upaya meningkatkan perilaku beragama ataupun penguatan norma bermasyarakat.

Secara posisi linguistik terminologis, ujaran manakib atau manaqiban menjadi unik dan juga menarik, karena masyarakat disamping menganggap pembacaan manakib sebagai ibadah ritual dan sekaligus berdimensi sufistik spiritualistik yang kental, disamping sebagai penghormatan dan rasa ta'dim pada Syaikh Abd al-Qodir al-Jailani yang di kalangan masyarakat sudah kondang sebagai punggawa para wali sedunia di segala zaman (wali Qutub) dalam segala rentang dan jenjang masa, -di sana- juga terjadi interaksi sosial dan kontak sosial antar anggota majlis manaqib yang juga bagian dari anggota masyarakat. Keadaan masyarakat dengan tingkat pengetahuan yang masih rendah dan tergolong awam, ditambah kesibukan serta rutinitas dalam keseharian, umumnya mencari penyegaran spritualitas dengan menghadiri majlis dzikir- majlis dzikir yang menawarkan ketenangan bathin. Sedang dzikir adalah bagian dari ibadah yang diperintahkan Allah SWT dalam alQur'an yang artinya:

"Wahai orang-orang yang beriman, ingatlah kepada Allah SWT dengan ingatan (dzikir) yang banyak". (QS. Al-Ahzab: 41)

Posisi vital dzikir adalah menjadi penghubung transenden antara makhluk dan sang Khalik, dan ritual manaqib, sebenarnya adalah upaya membumikan dzikir dengan manhaj serta metode yang variatif

\footnotetext{
16 Ibid. hal. 18. lihat juga http://id.wikipedia.org/wiki/Syekh Abdul_Qadir_ Jaelani

17 http://imambooks.blogspot.com/mulok-manaqib-syekh-abdul-qadir.html
} 
dengan diselingi dengan pembacaan manaqib serta umumnya diawali dengan mauidhah hasanah dari sang ketua jam'iyyah.

Posisi Manaqiban sebagai fenomena gerakan keagamaan yang unik dan menarik, dimana terdapatnya dialog intens antara tradisi sosial-budaya yang bersifat kultural dengan amaliah keagamaan yang bersifat spiritual teologis yang didesain berupa dzikir jama'i yang melebur dalam bentuk rangkaian dzikir istighatsah dan ditambah dengan pembacaan manaqib. Titik persinggungan riil disini, antara tradisi-budaya sosial yang disimbolkan dengan pelibatan masyarakat awam (baca:pinggiran) sebagai peserta (pelaku) aktif dalam kegiatan manaqiban yang diadakan di tengah-tengah mereka, di sisi yang lain adanya transfer hikmah (Wisdom), dan nilai-nilai spiritual yang terkandung dalam ajaran moral-sufistik Syaikh Abd al-Qodir al-Jailani diantaranya:

1). Dua karakter dari Allah yaitu dia menjadi seorang yang sattar (menutup aib) dan ghaffar (pemaaf). 2). Dua karakter dari Rasulullah SAW yaitu penyayang dan lembut. 3). Dua karakter dari Abu Bakar al-Siddiq r.a yaitu jujur dan dapat dipercaya. 4). Dua karakter dariUmar ibn Khattab ra yaitu amar ma'ruf nahi munkar. 5). Dua karakter dari Utsman bin Affan r.a yaitu dermawan dan bangun malam (Tahajjud) pada waktu orang lain sedang tidur. 6). Dua karakter dari Ali bin Abi Thalib r.a yaitu alim (cerdas/ intelek) dan pemberani. ${ }^{18}$ Dari deretan di atas dijelaskan dengan metode penjelasan yang runtut yang bersifat mauidhah dan taushiyah ditambahkan juga hal lain yang bernilai manfaat sebagai bekal positif yang berhubungan dengan kegiatan sehari-hari, seperti sifat sabar, ketekunan, sifat ajeg dan ikhlas, santun dan tawakkal serta ridha atas segala kepastian dari Sang Maha Kuasa.

Disamping hal tersebut, "adanya" faktor lain yang berupa semangat dan optimisme dalam beribadah yang memotivasi moral spiritual masyarakat untuk senantiasa beramal shalih dengan -selalu- berbuat kebaikan dalam kehidupan sehari-hari, berbaik sangka pada sesama, menghindari segala penyakit hati seperti sifat iri, dengki, hasud dan dendam, yang mana hal ini di sampaikan dengan bentuk nasehat-nasehat tentang kebaikan (mauidhah hasanah) oleh murshid atau kiyai pemimpin manaqiban, yang biasanya, dilakukan setelah mukaddimah, pembacaan al-Fatihah untuk arwah, sesepuh dan pinisepuh (bahasa jawa; ind.orang tua), dan para guru yang (telah) mendahului para jama'ah.

18 http://id.wikipedia.org/wiki/Syekh_Abdul_Qadir_Jaelani \#Ajaran-ajaranya
Selanjutnya, di dalam ritual dzikir manaqiban ini di samping adanya runtutan dzikir dan tahlil, juga ditambah dengan lantunan syiir yaa arhamar rahimin lalu disertai dengan penjelasan serta kesaksian (testimonial) tentang "sepak terjang" perjuangan dakwah Syaikh Abd al-Qodir al-Jailani disertai dengan kisahkisah kemuliaan (karamah), fadhilah al-Ilm wa alHikmah (keutamaan ilmu dan kebijaksanaan) yang di karuniakan oleh Allah SWT kepada beliau, tentunya dengan satu harapan, bahwa kisah itu dapat dijadikan sebagai panutan dan direnungkan sebagai suri tauladan, tut wuri handayani dalam hal mencapai kemuliaan ruhani oleh para jamaah manaqiban.

\section{Wujud ri'ayatul maslahat: dalam maqosid syariah dan tiga aspek kebutuhan terjaganya; dharuriyah, haajiyah dan tahsiniyah}

Sebagaimana dipahami, membincang adanya syariah diperuntukkan bagi kemaslahatan umat manusia, secara umum locus maslahat adalah mewujudkan manfaat, kebaikan, kesejahteraan dan kebahagiaan (kesenangan) untuk manusia, secara istilah di sebut membawa manfaat (jalbul manafi'), di sisi yang lain,adanya perintah Allah SWT juga mengandung menolak segala kerusakan (dar'ul mafasid) ${ }^{19}$ hal ini karena adanya keburukan, kejahatan dan penyimpangan perilaku sosial yang terjadi karena hati jauh dari kedekatan dengan Allah SWT, Sehingga yang menjadi panutan bukanlah perintah dan larangan Allah SWT tapi adalah hawa nafsu. Syariat Islam mengandung rahmat dan kemudahan sebagaimana di utusnya Nabi Muhammad SAW yang menjadi rahmat bagi semesta alam (QS. Al-Anbiyaa;:107). Sebagaimana juga ucapan Ibn al-qayyim al-Jauziyah bahwa seluruh syariat mengandung keadilan, rahmat, kemaslahatan dan hikmah. ${ }^{20}$

Dalam pembahasan sesuatu itu apakah terkandung maslahat di dalamnya harus melihat bahwa maslahat tersebut sesuai dengan maqashid syariah, harus meyakinkan, memiliki akurasi tinggi dengan berdasar penelitian bahwa hal tersebut mendatangkan manfaat dan menghindarkan mudharat, (baik dalam waktu dekat ataupun dalam masa jangka panjang), dapat dilaksanakan dan kemaslahatan itu bermanfaat bagi sebagian besar masyarakat serta bukan hanya di

19 Ibid.hal.222.

20 Yusuf Al-Qaradawi, Fiqih Maqashid Syariah, (Jakarta. Pustaka al-Kautsar, 2007) Hal. 154-155. Ibnu qayyim, menyebut washilah yang menuju maslahah di sebut Fath al-Dzariah (membuka jalan) pada kemaslahatan, sedangkang washilah menuju kedharatan di sebut Sadd al-Dzariah (menutup jalan). untuk Lihat dalam A. Djazuli, Kaidah-kaidah Fikih: Kaidah-Kaidah Hukum Islam Dalam Menyelesaikan masalah-masalah yang praktis", (Jakarta, Kencana, 2006). Hal. 30. 
nikmati oleh sebagian kecil dari mereka. ${ }^{21}$ Dari sini dapat diketahui, dalam struktur masyarakat yang menjadi tolok ukur untuk menentukan maslahat nya, atau manfaat dan mafsadatnya (baik dan buruknya) adalah sejauh mana hal itu menjadi kebutuhan dasar kehidupan manusia. Kebutuhan itu terbagi pada tiga tingkatan yaitu yang bersifat, dlaruriyah, hajiyaat dan tahsiniyat. ${ }^{22}$

Sedang Kebutuhan utama manusia (primer) yang mana tanpa terpenuhinya kebutuhan ini, keberadaan kehidupan manusia tidaklah sempurna, dan kebutuhan "primer" manusia ini dalam ushul fiqh disebut dengan dlaruriyah. Selanjutnya dlaruriyah diadakan dan di hadirkan, untuk melanggengkan adanya lima konsep maqashid syari'ah yang disebut juga dengan al-Ushul al-Khamsah, segala yang dapat mengekalkan kelima hal dasar pokok kelengkapan kehidupan manusia adalah sesuatau yang baik dan karena itu harus di kerjakan, dilanggengkan keberadaannya, sedang hal yang dapat mengurangi kelima hal itu adalah buruk karena itu adalah hal yang harus dijauhi dan kelima prinsip berurutan dalam Maqasid Syariah (tujuantujuan syariah) ${ }^{23}$ yang mutlak harus ada itu adalah: agama (din), jiwa (nafs), akal ('aql), harta (maal) dan keturunan (harga diri/ nasab).

Islam memiliki banyak konsep maupun metode dalam menekan (baca: meminimalisir) sedini mungkin adanya penyimpangan tersebut. posisi dzikir jama'i yang didesain dalam bentuk rangkaian dzikir dan pembacaan manaqib Syaikh Abd al-Qadir al-Jailani, secara ritual- teologis pada dasarnya adalah upaya untuk membentuk pribadi-pribadi yang memiliki akhlak utama dan mulia dalam hubungannya dengan Allah SWT dan pergaulan antar sesama manusia. Keberadaan dzikir jama'i yang "dikemas" dalam satu majlis dengan nama "majlis jama'ah manaqib Syaikh Abd al-Qadir al-Jailani" secara sosio-telogis memiliki arti signifikan dalam mewarnai dan "menjaga" pribadipribadi anggota Masyarakat, khususnya di kabupaten

21 Ibid.Hal. 29-30. Lihat juga: Wahbah Zuhaili. Ushul Fiqh al-Islamy Vol II. (Damascus. Darul al-fikr, 2005). Hal . 307.

22 Ibid. juz II. hal. 210-212. Lihat: Abdul Wahab Khallaf, Ilmu 'ushl Fiqh, (Jakarta. al-Haramaini, 2004). Hal. 84

23 Imam abu Ishaq al-Syatibi, seorang ulama' Andalusia yang hidup pada abadke-8 hijriyah atau 14 masehi $(730 \mathrm{H}-790 \mathrm{H})$, yang menekankan kajiannya seputar maqasid syari'ah pada enam poin berikut.1).Tujuan Allah dan Rasul-Nya dalam membuat syari' at agama bagi umat manusia,2). Tujuan Allah dan Rasul-Nya dalam memberikan pemahaman tentang syari'at kepada umat manusia,3).Tujuan Allah dan Rasul-Nya dalam membebankan hukum syari'at pada umat manusia,4).Tujuan Allah dan Rasul-Nya dalam mentargetkan hukum syari'at hanya pada kalangan mukallaf (orang dewasa dan berakal sehat) saja.5).Tujuan manusia dalam menjalankan hukum-hukum syari'at. 6).Metode untuk menguak maqasid syariah' (tujuan Allah dan Rasul-Nya). Lihat: http://www.fahmina.or.id/ artikel-a-berita/ para-pionir-kajian-maqasid-syariah.html
Probolinggo, kita ambil contoh dalam hal penguatan dan pengamalan nilai keagamaan, hubungan sosial, silaturrahim, dan norma serta etika masyarakat, lebih jelasnya yaitu:

a). Menjaga penyimpangan norma dan prilaku sosial akibat perkembangan situasi global dalam konteks moralitas dan etika yang makin permissif. b). Memperluas pengetahuan masyarakat tentang kaidahkaidah agama lewat taushiyah c). Memperkuat amalan beragama masyarakat d). Mempererat komunikasi sosial dan sekaligus sebagai ajang silaturahim informal diantara anggota masyarakat. e). Memperkuat rasa persaudaraan khususnya di kalangan jama' ah anggota manaqiban f). Mempercepat informasi-informasi yang berkaitan dengan kejadian sehari-hari di tengah masyarakat g). Memberi kemudahan penyampaian yang bersifat "promosi" hal-hal yang berkaitan dengan peningkatan ekonomi masyarakat khususnya di kalangan jama'ah istighatsah-manaqib utamanya oleh anggota jamaah sendiri. h). Mempermudah masyarakat dalam mengadakan kegiatan dengan membentuk kepanitiaan dalam rangka acara-acara peringatan hari besar keagamaan (Islam) seperti Maulid Nabi Muhammad SAW, Isra' Mi'raj, secara kolektif. Susunan di atas adalah beberapa faedah dan manfaat yang didapat dari pelaksanaan manaqib Syaikh Abd al-Qadir al-Jailani yang dirasakan oleh masyarakat, di samping rasa ketenangan bathin dan kedamaian sebagai efek dari mengingat Allah SWT dengan melakukan dzikir.

Melihat manfaat majlis manaqiban ini, secara umum bila dinilai dalam perspektif hukum syariah inilah yang di sebut sisi riayat al-Maslahat (Menjaga kemaslahatan). Dimana makna yang disebutkan oleh mayoritas peneliti, mereka membagi kemashlahatan menjadi dua macam, yaknikemashlahatan akhiratyang dijamin oleh akidah dan ibadah dan kemashlahatan dunia yang dijamin oleh muamalat. ${ }^{24}$ Karena pada

24 Sebagaimana pernyataan Izzudin Abdussalam (578H-660H), ketika membahas tentang acuan dasar dalam maslahat yang bersifat masholih dunyawiyah dan masholih ukhrowiyah yang masing-masing terbagi tiga sifat: 1). dhoruriyah,2). haajiyah dan 3). tahsiniyah. Di contohkan di sini, masholih yang bersifat dhoruriyah dunyawiyah: makanan, tempat tinggal, pakaian, sedang yang bersifat haajiyah dunyawiyah jenjang yang terdapat di antara keduanyadan tahapan tahsiniyah adalah sisi penyempurnaan dari aspek yang pertama semisal tempat tinggal yang layak huni, lingkungan sehat, dari sisi kesehatan, pakaian yang baik walau tidak harus mewah dan sesuai syariat (sopan dan menutup aurat bagi perempuan), juga memakan -makanan yang sehat, bergizi dan melangsungkan ikatan pernikahan yang baik sesuai syariah (dan undang-undang Negara). Selanjutnya maslahat yang bersifat ukhrowiyah yang bersifat dhoruriyah adalah melakukan amar ma'ruf dan menghindari segala larangan dan kemungkaran serta muharromat (halhal yang di haramkan oleh syariah), sedang dari sisi tahsiniyah adalah melakukan segala kesunnahan muakkad dan fadhilah-fadhilah (keutamaan) lain dalam ibadah, dan yang tahsiniyah ukhrowiyah adalah berperilaku dan hal-hal yang mandhubah. Lihat Hasani, Ismail. 1994. Nadhoriatul maqosid 
hakekatnya segala hal yang terkait dengan akidah, ibadah dan muamalat dalam syariat Islam menjamin segala kemashlahatan umat baik sisi dunia maupun akhirat kelak. ${ }^{25}$ Sebagaimana juga, makna maslahat secara sederhana dapat diartikan sebagai sesuatu yang baik, dapat diterima oleh akal sehat. Diterima -dalam artian- dapat diketahui dengan jelas, mengapa hal (tersebut) begitu adanya. ${ }^{26}$ Sebagaimana setiap perintah Allah SWT dapat dipahami oleh akal, kenapa Allah SWT menyuruh yaitu karena mengandung kemaslahatan untuk manusia. Perintah Shalat sebagai dzikir secara lugas disebutkan oleh Allah aspek manfaat dan kemaslahatannya, yaitu dapat mencegah perbuatan keji dan munkar, dan dzikir dengan (selalu) mengingat Allah SWT akan menimbulkan ketentraman hati. Sebagaimana Firman Allah dalam SWT, yang artinya:

"Ssesungguhnya Shalat itu dapat mencegah perbuatan keji dan munkar". (QS. Al-Ankabut: 45) dan Firman Allah SWT yang artinya: "Ketahuilah bahwa dengan berdzikir itu hati akan tentram". (alRa'd: 28). ${ }^{27}$

Sejurus dengan pemaknaan adanya kemaslahatan seperti di atas, Said Ramadhan al-Buthi menyatakan bahwa kemaslahatan asasi adalah satu, yaitu terciptanya penghambaan bagi seorang mukallaf kepada Allah dan ma'rifat billah. ${ }^{28}$ Al-Buthi mendasarkan pada Firman Allah SWT yang artinya: "Dan carilah pada apa yang telah dianugerahkan Allah kepadamu (kebahagiaan) negeri akhirat dan janganlah kamu melupakan bahagianmu dari (kenikmatan) duniawi" (QS. Al-Qashash: 77 )

Dimana pernyataan Syaikh Ramadhan al-Buthi menandaskan bahwa mayoritas ahli tafsir bersepakat bahwa pernyataan la tansa nashibaka min al dunya (janganlah kamu melupakan bahagianmu dari kenikmatan duniawi), adalah bermakna bagian dunia yang berfaedah bagi akhiratnya. ${ }^{29}$ Rasanya sulit dipungkiri, bahwa adanya manaqiban disamping berimbas secara spirituallitas-teologis dalam membangun dan menguatkan nilai-nilai religiusitas juga pengamalan dan menjaga kekuatan aspek nilai keberagamaan masyarakatawam dengan memperkokoh amaliah keagamaan mereka, agar selalu istiqomah dan ajeg, di samping

'inda Imam Muhammad thohir bin 'asyur, Virginia, International of Islamic Though (IIT). Hal. 52.

25 http://pesantren.or.id /ppssnh.malang/artikel/kolom gus/maqasid syariah. lihat: Muhammad Said Ramadhan Al-Buthi, Dhowabit al Mashlahah fi al Syariah al Islamiyah, (Beirut: Dar al Muttahidah, 1992). Hal. 77.

26 Amir Syarifuddin, Ushul Fiqh Jilid 2, (Jakarta, kencana, 2009). Hal. 220

27 Ibid. hal. 221.

28 Ibid. Hal . 112.

29 http://pesantren.or.id /ppssnh.malang/artikel/kolom_gus/maqasid_syariah juga memperkuat tali ikatan, mentalitas dan perilaku moral serta norma sosial yang sudah mengakar dan menjadi tradisi di tengah-tengah masyarakat.

\section{Kesimpulan}

Meletakkan sederetan konsep sosiologis, kita mengenal bahwa eksistensi individu dalam masyarakat dan relasi sosialnya merupakan tulang punggung sekaligus sebagai subyek pelaku dalam terbentuknya satu masyarakat ideal yaitu masyarakat utama yang dicita-citakan bersama dan juga sebagaimana tujuan bersama didirikannya satu komunitas yang bernama masyarakat. sebagaimana Emile Durkheim yang mengkaji dan mengulas tentang masyarakat ideal berdasarkan solidaritas sosial yang menunjuk pada satu keadaan hubungan antara individu dan atau kelompok yang berdasarkan pada perasaan moral dan kepercayaan yang dianut bersama yang diperkuat oleh pengalaman emosional bersama, juga terdapat adanya penyimpangan sosial (anomie) akibat percepatan perkembangan waktu dan informasi. Selain itu Max Weber yang membahas tentang perilaku individu dan hubungan sosial.

Gerakan fenomenal dari membumikan ajaran Syaikh Abd al-Qadir al-Jailani yang kental nuansa sufistik dengan format dzikir, yang di ikuti oleh sebagian besar masyarakat pesisir pantai pulau jawa -termasuk masyarakat kabupaten probolinggodengan bentuk dan sebutan yang berbeda tapi nyaris sama dalam prakteknya yaitu dengan membaca kitab manaqib beliau dan ditambah tahlil dan dzikir, dalam hal ini kitab yang dibaca adalah kitab manaqib Nurul Burhan, yang berjudul lengkap: "AnNurul Burhani fi tarjamatil Lujjainid Dani fi Dzikri Nubdzatin min Manaqib al-Syaikh Abd al-Qadir AlJailani" dan sebutan majelisnyapun berbeda, dengan istilah kultural seperti misalnya: manaqiban, dzikir manakib, istighotsah-manaqib dan lain sebagainya. Sejatinya makna yang ditangkap dari manaqiban adalah cerita hikmah atau kisah yang baik dari beliau. Adalah maklum, bila melihat ritual dzikir jama'i ini disatu sisi dalam mencipta keseimbangan perilaku dan norma sosial serta di sisi yang lain adalah dalam rangka meminimalisir penyimpangan etika masyarakat. Tidak terlupakan didalamnya adanya upaya konstruktif dalam memperkuat komunikasi sosial dan jalinan silaturrahmi antar masyarakat. Tentunya semangat spiritualitas dari ritual ini yang menjadi penanda dan perekat sosial serta di dalamnya sarat dengan nilai kemaslahatan baik yang bersifat dunyawiyah dan ukhrawiyah. Membincang ko- 
relasi tradisi manaqiban dan peran aktifnya dalam memperkuat pengamalan nilai-nilai spiritual, moral dan norma sosial di tengah-tengah masyarakat bisa disebut cukup kuat, begitu pula dilihat dalam perspektif maslahat ritual ini terdapat dalam lima hal yaitu

\section{Daftar Pustaka}

Abu Raihan. Pemikian Ibnu Maskawiah dan Ibnu Thufail. (http:// abulraihan.wordpress.com. diakses 8 Juni 2011)

Al-Buthi, Muhammad Said Romadlon,1992. Dhowabit al Mashlahah fi al Syariah al Islamiyah. Beirut: Dar al Muttahidah.

Al-Qaradawi, Yusuf. 2007. Fiqih Maqashid Syariah. Jakarta. Pustaka al-Kautsar.

Definis dari Sudut Pandang. (http://id.shvoong.com. Diakses 14 Juni 2011)

Definis Tasawuf (Penyejuk Hati). (http://irdy74. multiply.com/recipes/item/60. diakses 21 Juni 2011)

Definisi Tasawuf. (http://akhfa.blogspot.com. Diakses 19 Juni 2011)

Djazuli, A. 2006. Kaidah-kaidah Fikih: KaidahKaidah Hukum Islam Dalam Menyelesaikan masalah-masalah yang praktis. Jakarta, Kencana.

Emile Durkheim. (http://id.wikipedia.org. diakses 14 Juni 2011)

Hasani, Ismail. 1994. Nadhoriatul maqosid 'inda Imam Muhammad thohir bin 'asyur. Virginia, International of Islamic Though (IIT)

http://id.wikipedia.org/wiki/Syekh_Abdul_Qadir_ Jaelani \#Ajaran-ajaranya/ di akses 17 juni

Khallaf, Abdul Wahab. 2004. Ilmu 'ushl Figh. Jakarta. al-Haramaini.

Maqasid Syariah. (http://pesantren.or.id/ppssnh.malang /artikel/kolom_gus. Diakses 21 Juni 2011) menjaga nilai: agama, jiwa, akal, harta dan keturunan (harga diri) dengan tingkat kebutuhan yang mengekalkannya baik bersifat primer (dlarury), sekunder ( hajjy) dan tersier (tahsiny).

Mulok Manaqib Sykeh Abdul Qadir. (http:// imambooks.blogspot.com. Diakses 16 Juni 2011)

Norma dan Nilai Sosial. (http://saiyanadia.wordpress. com. Diakses 15 Juni 2011)

Para Pioner Kajian Maqasid Syariah. (http://www. fahmina.or.id/artikel-a-berita. diakses 29 Juni 2011)

Rahmatan lil Alamin. (http://republika.co.id/berita/ ensiklopedia-islam/hikmah/-rahmatan-lilalamin/. Diakse 2 Juli 2011)

Sekh Abdul Qadir Jaelani dan Ajarannya. (http:// id.wikipedia.org/wiki/. Diakses 17 Juni 2011)

Society. (http://en.wikipedia.org. diakses 12 Jui 2011)

Soeryono soekanto. 2002.Mengenal Tujuh Tokoh Sosiologi. Jakarta, Raja Grafindo Persada

Syamsuri, Baidhowi,Penuntun Manaqib Syeikh Abdul Qadir al-Jailani dengan Terjemah". Surabaya, Apollo.

Syarifuddin, Amir. 2009. Ushul Fiqh Jilid 2. Jakarta, kencana.

Syarifudin, Amir, 2003, Garis-Garis Besar Fiqh. Bogor, Prenada Media

Syekh Abdul Qodir Jaenali. (http://id.wikipedia.org/ wiki/. Diakses 16 Juni 2011)

Teori Sosiologi Modern. (http://pustaka.ut.ac.id. Diakses 12 Juni 2011)

Zuhaili, Wahbah. 2005. Ushul Figh al-Islamy. Damascus. Darul al-fikr. Juz II. 